\title{
Az elhízás és a cukorbetegség légzőrendszeri következményei
}

\author{
Kovács Barbara Nóra dr. ${ }^{1,2^{*}}$ - Südy Roberta dr. ${ }^{1,2^{*}}$ - Peták Ferenc dr. ${ }^{{ }^{*}}$ \\ Balogh Ádám László dr. ${ }^{1,2}$ - Fodor H. Gergely dr. ${ }^{2}$ \\ Tolnai József $\mathrm{dr}^{2}{ }^{2}$ - Korsós Anita dr. ${ }^{1}$ - Schranc Álmos dr. ${ }^{2}$ \\ Lengyel Csaba dr. ${ }^{3}$ - Babik Barna dr. ${ }^{1}$ \\ ${ }^{1}$ Szegedi Tudományegyetem, Általános Orvostudományi Kar, \\ Aneszteziológiai és Intenzív Terápiás Intézet, Szeged \\ ${ }^{2}$ Szegedi Tudományegyetem, Általános Orvostudományi Kar, \\ Orvosi Fizikai és Orvosi Informatikai Intézet, Szeged \\ ${ }^{3}$ Szegedi Tudományegyetem, Általános Orvostudományi Kar, Belgyógyászati Klinika, Szeged
}

Bevezetés: A cukorbetegségben nő a simaizmok tónusa, és megváltozik az elasztin és a kollagén szerkezete. Mivel a tüdőszövetben ezek a strukturális elemek meghatározóak, a cukorbetegség várhatóan módosítja a légutak és a tüdőszövet mechanikai és funkcionális viselkedését.

Célkitüzés: Vizsgálatunk során diabetesben szenvedő, elhízott és nem elhízott betegeink körében tanulmányoztuk a légzésmechanikai elváltozásokat és a gázcserefunkciót.

Módszer: Elektív szívsebészeti beavatkozásra kerülő, normál testalkatú betegeket diabetesben nem szenvedő $(\mathrm{n}=80)$, illetve cukorbeteg $(n=35)$ csoportokra osztottuk. További két betegcsoportba elhízott és nem cukorbeteg $(n=47)$, valamint elhízott és diabetesben szenvedő $(\mathrm{n}=33)$ betegek kerültek. A légzőrendszer mechanikai tulajdonságait kényszerített oszcillációs technikával határoztuk meg, mellyel a légúti ellenállás (Raw), valamint a szöveti csillapítás $(\mathrm{G})$ és rugalmasság $(\mathrm{H})$ tényezői jellemezhetôk. Volumetriás kapnográfia segítségével a kapnogram 3. fázisának meredekségét és a légzési térfogat különböző ventilációs/perfúziós illeszkedési zavaraiból adódó holttérfrakciókat határoztuk meg. Az intrapulmonalis shuntfrakciót és az oxigenizációs indexet $\left(\mathrm{PaO}_{2} / \mathrm{FiO}_{2}\right)$ artériás és centrális vénás vérgázmintákból határoztuk meg.

Eredmények: A megfelelő kontrollcsoportokhoz hasonlítva a cukorbetegség önmagában is növelte az Raw $(7,4 \pm 5$ vs. $\left.3,0 \pm 1,7 \mathrm{H}_{2} \mathrm{Ocm} . \mathrm{s} / \mathrm{l}\right)$, a $\mathrm{G}\left(11,3 \pm 4,9\right.$ vs. $\left.6,2 \pm 2,4 \mathrm{H}_{2} \mathrm{Ocm} / \mathrm{l}\right)$ és a $\mathrm{H}\left(32,3 \pm 12,0\right.$ vs. $\left.25,1 \pm 6,9 \mathrm{H}_{2} \mathrm{Ocm} / \mathrm{l}\right)$ értékét ( $\mathrm{p}<0,001$ mindegyik betegcsoportnál), de ez nem járt együtt a gázcserefunckció romlásával. Hasonló patológiás elváltozásokat észleltünk elhízás során a légzésmechanikában és az alveolaris heterogenitásban, amelyek azonban a gázcsere hatékonyságát is rontották.

Következtetés: Cukorbetegségben a légzésmechanika romlását a fokozott hypoxiás pulmonalis vasoconstrictio ellensúlyozni képes, ezzel kivédve az intrapulmonalis shunt növekedését és az oxigenizációs képesség romlását. Orv Hetil. 2022; 163(2): 63-73.

Kulcsszavak: diabetes mellitus, testtömegindex, légzésmechanika, kapnográfia, gázcsere

\section{Respiratory consequences of obesity and diabetes}

Introduction: While sustained hyperglicemia affects the smooth muscle tone and the elastin-collagen network, the effect of diabetes mellitus on the function and structure of the airways and the lung parenchyma has not been characterized, and the confounding influence of obesity has not been elucidated.

Objective: To reveal the separate and additive roles of diabetes mellitus and obesity on the respiratory function. Method: Non-obese mechanically ventilated patients were categorized as control non-diabetic $(\mathrm{n}=80)$ and diabetic $(\mathrm{n}=35)$ groups. Obese patients with $(\mathrm{n}=33)$ or without $(\mathrm{n}=47)$ associated diabetes were also enrolled. Forced oscillation technique was applied to measure airway resistance (Raw), tissue damping $(\mathrm{G})$, and tissue elastance $(\mathrm{H})$. Capnography was utilized to determine phase 3 slopes and ventilation dead space parameters. Arterial and central venous blood samples were analyzed to assess intrapulmonary shunt fraction (Qs/Qt) and the lung oxygenation index $\left(\mathrm{PaO}_{2} / \mathrm{FiO}_{2}\right)$.

Results: Diabetes without obesity increased the Raw $\left(7.4 \pm 5 \mathrm{cmH}_{2} \mathrm{O} . \mathrm{s} / 1\right.$ vs. $\left.3.0 \pm 1.7 \mathrm{cmH}_{2} \mathrm{O} . \mathrm{s} / \mathrm{l}\right), \mathrm{G}(11.3 \pm 4.9$ $\mathrm{cmH}_{2} \mathrm{O} / \mathrm{l}$ vs. $\left.6.2 \pm 2.4 \mathrm{cmH}_{2} \mathrm{O} / \mathrm{l}\right)$, and $\mathrm{H}\left(32.3 \pm 12.0 \mathrm{cmH}_{2} \mathrm{O} / \mathrm{l} v s .25 .1 \pm 6.9 \mathrm{cmH}_{2} \mathrm{O} / \mathrm{l},(\mathrm{p}<0.001\right.$ for all $)$, compared with the corresponding control groups. Capnographic phase 3 slope was increased in diabetes without signifi- 
cant changes in $\mathrm{PaO}_{2} / \mathrm{FiO}_{2}$ or Qs/Qt. While similar detrimental changes in respiratory mechanics and alveolar heterogeneity were observed in obese patients without diabetes, these alterations also compromised gas exchange.

Conclusion: The intrinsic mechanical abnormalities in the airways and lung tissue induced by diabetes are counterbalanced by hypoxic pulmonary vasoconstriction, thereby maintaining intrapulmonary shunt fraction and oxygenation ability of the lungs.

Keywords: diabetes mellitus, body mass index, respiratory mechanics, capnography, gas exchange

Kovács BN, Südy R, Peták F, Balogh ÁL, Fodor H. G, Tolnai J, Korsós A, Schranc Á, Lengyel Cs, Babik B. [Respiratory consequences of obesity and diabetes]. Orv Hetil. 2022; 163(2): 63-73.

(Beérkezett: 2021. június 16.; elfogadva: 2021. július 26.)

\section{Rövidítések}

AGE $=($ advanced glycation endproduct $)$ előrehaladott glikációs végtermék; ANOVA $=$ (analysis of variance $)$ varianciaanalízis; $\mathrm{BMI}=($ body mass index $)$ testtömegindex; $\mathrm{C}=$ légzőrend szeri compliance; $\mathrm{CcO}_{2}=$ a kapilláris vér oxigéntartalma; $\mathrm{CaO}_{2}$ $=\mathrm{az}$ artériás vér oxigéntartalma; $\mathrm{CvO}_{2}=\mathrm{a}$ vénás vér oxigéntartalma; $\mathrm{C}-\mathrm{N}=$ diabetesben nem szenvedő kontrollbetegek; $\mathrm{C}-\mathrm{O}=$ diabetesben nem szenvedő, elhízott betegek; COPD = (chronic obstructive pulmonary disease) krónikus obstruktív tüdőbetegség; $\mathrm{D}-\mathrm{N}$ = diabetesben szenvedő kontrollbetegek; $\mathrm{D}-\mathrm{O}=$ diabetesben szenvedő, elhízott betegek; $\mathrm{ETCO}_{2}=\mathrm{a}$ kilégzésvégi szén-dioxid parciális nyomása; $\mathrm{FEV}_{1}=($ forced expiratory volume in 1 second) eróltetett kilégzési másodperctérfogat; $\mathrm{FiO}_{2}=$ (fraction of inspired oxygen) belélegzett oxigénkoncentráció; $\mathrm{G}=$ a szöveti csillapítás tényezője; $\mathrm{H}$ = a szöveti rugalmasság tényezője; HbAlc = hemoglobin- $\mathrm{A}_{\mathrm{lc}} ; \mathrm{Iaw}=$ légúti inertancia $; \mathrm{Pao}=$ légúti bemeneti nyomás $\mathrm{PaCO}_{2}=$ parciális $\mathrm{CO}_{2}$-nyomás az artériás vérben; $\mathrm{PaO}_{2}=$ parciális $\mathrm{O}_{2}$-nyomás az artériás vérben; $\mathrm{PaO}_{2} / \mathrm{FiO}_{2}=$ oxigenizációs index; $\mathrm{PECO}_{2}=$ (partial pressure of mean expired $\mathrm{CO}_{2}$ ) a kevert kilélegzett $\mathrm{CO}_{2}$ parciális nyomása; $\mathrm{PEF}=$ (peak expiratory flow) légúti csúcsáramlás $; \mathrm{PEEP}=$ (positive end-expiratory pressure $)$ pozitív végkilégzési nyomás; Qs/Qt = a Berggren-egyenlettel kapott intrapulmonalis shunt; $\mathrm{R}=$ légzőrendszeri ellenállás; Raw = légúti ellenállás; S3T = az idótartomány-beli kapnogram 3 . fázisának meredeksége; $S 3 V=$ a volumetriás kapnogram 3. fázisának meredeksége; T2DM = (type 2 diabetes mellitus) 2 -es típusú cukorbetegség; $\mathrm{V}^{\prime}=$ centrális légáramlás; $\mathrm{VDB}=\mathrm{Bohr}-$ féle fiziológiás holttér; VDE = Enghoff-holttér; VDF = Fowlerszerinti anatómiai holttér; VT = (tidal volume) légzési térfogat; Zrs = a légzőrendszer bemeneti impedanciája

A cukorbetegség világszerte jelentős terhet ró az egészségügyi ellátórendszerre [1-5]. A 2-es típusú cukorbetegség (T2DM) képezi a diabetes különböző megjelenési formáinak döntő többségét (90-95\%). Az intenzív terápiás ellátást igénylő, diagnosztizált és még diagnosztizálatlan cukorbetegségben szenvedő betegek száma az elmúlt évtizedben folyamatosan nőtt; az incidencia mára eléri a 25-40\%-ot [6-9]. Következésképpen a cukorbetegek mindenre kiterjedő ellátása egyre inkább meghatározó tényezôvé válik az egészségügyben dolgozók számára.

A kóros metabolikus folyamatok egyik fontos következménye az oxidatív stressz növekedése, mely hozzájá- rul az endothelsejt-diszfunkcióhoz [10]. Ez a kóros tendencia a vasoconstrictor és vasodilatator mechanizmusok egyensúlyának eltolódásában manifesztálódik, melyre az endotelin-1 túlzott expressziója, valamint a nitrogénmonoxid csökkent biohasznosulása és a prosztaglandin $\mathrm{I}_{2}$ csökkent szintézise is jellemző $[8,11]$. A tartósan magas vércukor az előrehaladott glikációs végtermékek (AGE-k) emelkedett szintjéhez vezet $[8,9,12,13]$. A simaizomzat miozin-könnyúláncának fokozott foszforilációja következtében a vascularis contractilis tónus tovább emelkedik [6, 14]. A kóros sejtszintû mechanizmusok közé tartozik az apoptosis, a vascularis permeabilitás, a vascularis tónus és a prothromboticus és proinflammatoricus folyamatok fokozódása, valamint az extracelluláris mátrix proliferációja $[6,8-12,15]$.

Az eddig ismertetett kórélettani változások a tüdő érintettségét is felvetik. A kóros metabolikus miliő a légúti simaizomzat tartós constrictiójához vezethet, az AGE-k termelődése révén pedig strukturálisan károsítja a tüdő kollagénszerkezetét. A szisztémás vascularis elváltozások természetszerúleg a pulmonalis érrendszerben is megjelennek $[9,12,15]$. Mindezen folyamatok a tüdő múködésének, funkciójának romlásához is hozzájárulnak [16].

A cukorbetegség légzésfunkcióra gyakorolt hatásának tisztázása céljából végzett vizsgálatok során az irodalmi adatok egyaránt jeleznek romló [17-20] és változást nem mutató spirometriás eredményeket [21-24]. Az ellentmondásos eredményekhez a spirometria már jól ismert korlátain kívül $[25,26]$ a vizsgált populációk közötti lényeges különbségek (például a cukorbetegség típusa és súlyossága, az életkor és a társbetegségek) is hozzájárulhattak. A tisztánlátást tovább nehezítheti a konkomittáló elhízás, mely a cukorbetegségtől nem elválasztva az objektív értékelést lehetetlenné teszi.

Ezek alapján célul tűztük ki a cukorbetegség és az elhízás mint önálló patológiás tényezők hatásainak vizsgálatát a légúti funkcióra és a tüdőszövetek viszkoelasztikus mechanikai tulajdonságaira. Továbbá arra kerestük a választ, hogy a cukorbetegség önmagában hogyan befolyásolja a ventilációs heterogenitást, a ventilációs-perfúziós illeszkedést, valamint a gázcserét az intenzív terápiás klinikai gyakorlatban szívsebészeti perioperatív ellátás során. 


\section{Anyagok és módszer}

\section{Betegek és betegcsoportok}

A prospektív vizsgálatba 195 , elektív szívmútétre kerüló beteget válogattunk be. A betegeket az esetleges anyagcsere-betegségük alapján négy csoportba soroltuk. Azon betegek, akiknek a testtömegindexe (BMI) $30 \mathrm{~kg} / \mathrm{m}^{2}$ alatti volt, a nem elhízott betegcsoportba kerültek, akiket tovább kategorizáltunk T2DM-ben nem szenvedó kontroll $(\mathrm{C}-\mathrm{N}, \mathrm{n}=80)$ és diabetesben szenvedő (D-N, $\mathrm{n}=35)$ betegekre. Az elhízott betegeket $(\mathrm{BMI} \geq 30$ $\left.\mathrm{kg} / \mathrm{m}^{2}\right)$ a cukorbetegség megléte $(\mathrm{D}-\mathrm{O}, \mathrm{n}=33$ ) vagy hiánya $(\mathrm{C}-\mathrm{O}, \mathrm{n}=47)$ szerint osztottuk az előbbiekhez hasonlóan további két csoportra.

A T2DM-kórállapot fennállását igazolta, ha a beteg kórtörténetében szerepelt a T2DM diagnózisa és/vagy a hemoglobin- $\mathrm{A}_{\mathrm{lc}}\left(\mathrm{HbA}_{\mathrm{lc}}\right)$ szintje $>6,4 \%$ volt.

Vizsgálatunk során kizáró kritériumokként fogalmaztuk meg a következő feltételeket: 80 év feletti életkor, alacsony ejekciós frakció $(<40 \%)$, dohányzás, krónikus obstruktív tüdőbetegség (COPD) megléte.

A vizsgálati protokollt a Szegedi Tudományegyetem Humán Kutatásetikai Bizottsága hagyta jóvá (WHO 2788. sz.), a betegek felvilágosítást követően írásbeli beleegyezésüket adták a vizsgálatban történő részvételhez. A klinikai vizsgálat nemzetközi regisztrációs száma: NCT03768973 (www.clinicaltrials.gov).
A tanulmányt az 1964-es Helsinki Nyilatkozatban és annak későbbi módosításaiban meghatározott etikai normáknak megfelelően végeztük, a vizsgálat a CONSORTirányelveket követte. A betegek beválogatását és csoportbesorolását az 1. ábra mutatja.

\section{Anesztézia és betegmonitorozás}

A mútét előtt egy órával a betegeket per os lorazepámmal $(2,5 \mathrm{mg})$ premedikáltuk. Az indukció midazolám (30 $\mu \mathrm{g} / \mathrm{kg})$, sufentanil $(0,4-0,5 \mu \mathrm{g} / \mathrm{kg})$ és propofol $(0,3-$ $0,5 \mathrm{mg} / \mathrm{kg}) i$. alkalmazásával, fenntartása pedig $i v$. propofollal $(50 \mathrm{mcg} / \mathrm{kg} /$ perc $)$ történt. A neuromuscularis blokád céljából $i$. rokuroniumbolust adtunk $(0,8 \mathrm{mg} /$ $\mathrm{kg}$ indukcióhoz és $0,2 \mathrm{mg} / \mathrm{kg} 30$ percenként fenntartáshoz). Az endotrachealis intubatiót 7, 8, illetve $9 \mathrm{~mm}$ belső átmérójǘ endotrachealis tubussal végeztük. A betegeket térfogat-szabályozott üzemmódban csökkenő áramlással lélegeztettük (Dräger Zeus, Lübeck, Németország), $7 \mathrm{ml} / \mathrm{kg}$ légzési térfogat (VT) és $4 \mathrm{H}_{2} \mathrm{Ocm}$ pozitív végkilégzési nyomás (PEEP) alkalmazásával. A légzési frekvencia 12-14/perc közti értékével a kilégzésvégi szén-dioxid parciális nyomását $\left(\mathrm{ETCO}_{2}\right) 36-40 \mathrm{Hgmm}$ en tartottuk, míg a belélegzett oxigénfrakció $\left(\mathrm{FiO}_{2}\right)$ értékét 0,5-re állítottuk a vizsgálati időtartam alatt. Centrális vénás katétert vezettünk a jobb vena jugularisba, valamint a bal oldali radiális artériát használtuk az artériás nyomás monitorozására, illetve vérgázminták vételére.

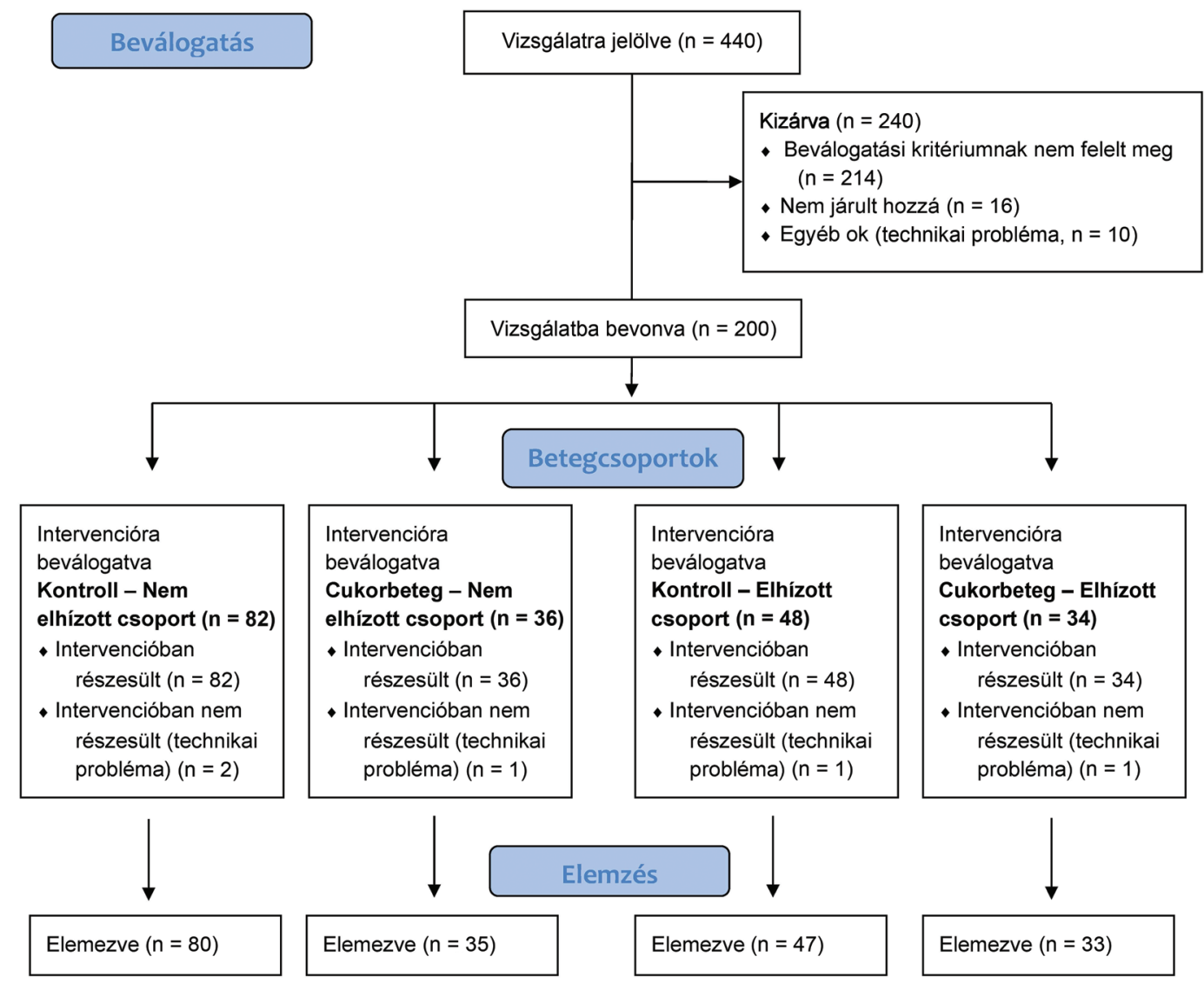

1. ábra

| Folyamatábra a betegek vizsgálati részvételéről 


\section{A légutak és a tüdöszövetek mechanikai tulajdonságainak mérése}

A légutak és a tüdőszövet mechanikai tulajdonságainak szeparált jellemzésére alacsony frekvenciás kényszerített oszcillációs technikát alkalmaztunk. A légzőrendszer bemeneti impedanciájának (Zrs) mérését és elemzését korábbi tanulmányainkban már részleteztük [27]. A mérési összeállításban egy zárt hangszóródoboz-rendszert egy kollapszibilis T-idommal az endotrachealis tubushoz csatlakoztattunk. A mérések előtt a tüdőt 3-4 másodpercig tartott $30 \mathrm{H}_{2} \mathrm{Ocm}$ nyomással toboroztuk a térfogati állapot standardizálása céljából. Alacsony frekvenciás $(0,2-6 \mathrm{~Hz})$ kényszerített oszcillációs jelet alkalmaztunk a kilégzésvégi, rövid (15 másodperces) apnoés periódus alatt. A centrális légáramlást (V') $28 \mathrm{~mm}$-es belső átmérőjü szita-pneumotachográffal mértük, melyet differenciális nyomásmérőhöz csatlakoztattunk (ICS 33NA002D modell; IC Sensors, Milpitas, CA, USA). A légúti bemeneti nyomást (Pao) egy, az előbbivel megegyező nyomásméróvel detektáltuk. A Zrs-t a Pao és V' jelek teljesítménysürúség-spektrumából számoltuk. Az állapotonként átlagolt Zrs-adatokra egy matematikai modellt illesztve nyertük ki [28] a frekvenciától független légúti ellenállást (Raw) és légúti inertanciát (Iaw), valamint a konstans fázisú szöveti mechanikai paramétereket, melyek a szöveti csillapítással $(\mathrm{G})$ és a szöveti rugalmassági tényezővel $(\mathrm{H})$ jellemezhetók. A respirátor által kijelzett teljes légzőrendszeri ellenállást $(\mathrm{R})$ és compliance-t $(\mathrm{C})$ is regisztráltuk. A kényszerített oszcillációs méréseket a teljes instrumentális ellenállás levonásával korrigáltuk.

\section{A volumetriás kapnogram rögzitése és elemezése}

A kilégzett gáz $\mathrm{CO}_{2}$ parciális nyomásának változását a lélegeztetés során fóáramú kapnográffal (Capnogard Model 1265, Novametrix, Andover, MA, USA) mértük. A 15 másodperc hosszú méréseinket 102,4 Hz-es mintavételi frekvenciával digitalizáltuk, számítógépen tároltuk, és saját fejlesztésú szoftverrel elemeztük, a korábbi tanulmányunkban részletezett eljárásoknak megfelelően [29].

Az időtartomány-beli (S3T) és a volumetriás kapnogram $(\mathrm{S} 3 \mathrm{~V}) 3$. fázisa meredekségének meghatározásához regressziós egyenest illesztettünk a 3. fázis utolsó $60 \%$ ára [29]. Az S3T kifejezi a kilélegzett gáz parciális $\mathrm{CO}_{2}$ nyomásának változását egységnyi idő alatt $(\mathrm{Hgmm} / \mathrm{s})$, míg az S3V mindezt egységnyi térfogatváltozás alatt $(\mathrm{Hgmm} / \mathrm{l})$. A ventiláció hatékonyságát csökkentő légzésiholttér-paramétereket a volumetriás kapnogramokból számoltuk. A Fowler szerinti anatómiai holtteret (VDF), amely a gázcserében részt nem vevő vezetô légutak térfogatát tükrözi [30], a kilégzés kezdetétől a volumetriás kapnogram 2. fázisának inflexiós pontjáig kilégzett térfogatként értelmeztük [31].
A Bohr-féle fiziológiás holtteret (VDB), mely magában foglalja az elóbbiek mellett a csökkent vagy megszűnt perfúziójú alveolaris térfogatot is, az alábbi képlet alapján számítottuk:

$$
\mathrm{VDB} / \mathrm{VT}=\left(\mathrm{PACO}_{2}-\mathrm{PECO}_{2}\right) / \mathrm{PACO}_{2},
$$

ahol a $\mathrm{PACO}_{2}$ a $\mathrm{CO}_{2}$ átlagos alveolaris parciális nyomása a 3. fázis felezópontjából meghatározva [32], a $\mathrm{PE}_{\bar{E}} \mathrm{CO}_{2}$ a kevert kilélegzett $\mathrm{CO}_{2}$ parciális nyomása, mely a volumetriás kapnogram görbe alatti területének és a légzési térfogatnak (VT) a hányadosa. A ventiláció/perfúzió illeszkedés becsléséhez az Enghoff-holtteret (VDE) határoztuk meg, mely a Bohr-holttérhez viszonyítva azon tüdőterületeket is magában foglalja, melyeknek alveolusai fenntartott perfúzióval, de csökkent ventilációval rendelkeznek, vagy a ventilációban egyáltalán részt nem vevő területekként, alveolaris shunt formájában vannak jelen. Ezt a következóképpen számoltuk:

$$
\mathrm{VDE} / \mathrm{VT}=\left(\mathrm{PaCO}_{2}-\mathrm{P}_{\bar{E} C O}\right) / \mathrm{PaCO}_{2},
$$

ahol a $\mathrm{PaCO}_{2}$ az artériás vérben mért $\mathrm{CO}_{2}$ parciális nyomása.

Az Enghoff- és a Bohr-holttér paraméterei közötti különbséget (VDE-VDB) az intrapulmonalis shunt becsléseként értelmeztük [31, 33].

\section{Vérgázanalizis és gázcsere-paraméterek}

A $\mathrm{PaO}_{2} / \mathrm{FiO}_{2}$ arány kiszámításához az artériás vérgázmintákból meghatározott oxigén parciális nyomását elosztottuk az $\mathrm{FiO}_{2}$-vel.

Az intrapulmonalis shuntfrakciót (Qs/Qt) a Berggrenegyenlet segítségével határoztuk meg [31]:

$$
\mathrm{Qs} / \mathrm{Qt}=\left(\mathrm{CcO}_{2} \mathrm{a}-\mathrm{CaO}_{2}\right) /\left(\mathrm{CcO}_{2}-\mathrm{CvO}_{2}\right) \text {, }
$$

ahol a $\mathrm{CcO}_{2}, \mathrm{a} \mathrm{CaO}_{2}$ és a $\mathrm{CvO}_{2}$ a tüdőben a kapilláris, az artériás és a centrális vénás vér oxigéntartalmát jelenti.

$\mathrm{A} \mathrm{CcO}_{2}-\mathrm{t}$ az alveolaris gázegyenletból számítottuk:

$$
\begin{gathered}
\mathrm{CcO}_{2}=1,34 \mathrm{ml} / \mathrm{g} \times \mathrm{Hb}+\mathrm{Sol} \times \\
\left(\mathrm{FiO}_{2} \times 7 \mathrm{l} 3 \mathrm{Hgmm}-\mathrm{PaCO}_{2} / 0,8\right)
\end{gathered}
$$

ahol az 1,34 ml/g a Hüfner-állandó, a Hb a hemoglobinkoncentráció grammban meghatározva, a Sol az oldhatósági együttható $(0,0031 \mathrm{ml} / 100 \mathrm{ml} / \mathrm{Hgmm})$, a $713 \mathrm{Hgmm}$ a vízgőz nélküli gáznyomás, a $\mathrm{PaCO}_{2}$ pedig a $\mathrm{CO}_{2}$ parciális nyomása az artériás vérben. A számításhoz feltételeztük, hogy a hemoglobin oxigéntelítettsége a pulmonalis kapillárisokban $100 \%$.

\section{Mérési protokoll}

A mútéti beavatkozás megkezdése előtt a méréseket általános anesztéziában, izomrelaxánsok hatása mellett vé- 
1. táblázat |A betegcsoportok antropometriai adatai, a betegek protokoll szerinti csoportosítása

\begin{tabular}{|c|c|c|c|c|c|}
\hline & $\begin{array}{c}\mathrm{C}-\mathrm{N} \\
(\mathrm{n}=80)\end{array}$ & $\begin{array}{c}\mathrm{D}-\mathrm{N} \\
(\mathrm{n}=35)\end{array}$ & $\begin{array}{c}\mathrm{C}-\mathrm{O} \\
(\mathrm{n}=47)\end{array}$ & $\begin{array}{c}\mathrm{D}-\mathrm{O} \\
(\mathrm{n}=33)\end{array}$ & $\mathrm{p}$ \\
\hline Testtömeg (kg) & $71,4 \pm 12,9$ & $74,0 \pm 9,1$ & $97,2 \pm 17,1$ & $93,3 \pm 16,1$ & $<0,001$ \\
\hline Testmagasság $(\mathrm{cm})$ & $167,3 \pm 8,9$ & $168,0 \pm 6,2$ & $167,7 \pm 11,5$ & $162,6 \pm 6,2$ & 0,088 \\
\hline $\operatorname{BMI}\left(\mathrm{kg} / \mathrm{m}^{2}\right)$ & $25,4 \pm 0,8$ & $26,1 \pm 1,2$ & $34,0 \pm 1,2$ & $35,6 \pm 1,7$ & $<0,001$ \\
\hline Életkor (év) & $68,2 \pm 10,9$ & $69,9 \pm 7,3$ & $67,1 \pm 10,7$ & $69,9 \pm 7,4$ & 0,53 \\
\hline Ejekciós frakció (\%) & $62,2 \pm 6,1$ & $60,1 \pm 7,4$ & $61,9 \pm 6,4$ & $59,2 \pm 7,6$ & 0,14 \\
\hline Vércukor (mmol/l) & $6,17 \pm 1,1$ & $8,62 \pm 3,36$ & $6,65 \pm 1,66$ & $8,16 \pm 2,92$ & $<0,001$ \\
\hline $\mathrm{HbA}_{\mathrm{lc}}(\%)$ & $5,63 \pm 0,37$ & $7,12 \pm 1,39$ & $5,62 \pm 0,43$ & $7,19 \pm 1,06$ & $<0,001$ \\
\hline T2DM fennállása (év) & - & $9,5 \pm 8,5$ & - & $11,0 \pm 8,8$ & 0,5 \\
\hline
\end{tabular}

$\mathrm{BMI}=$ testtömegindex; $\mathrm{C}-\mathrm{N}=2$-es típusú diabetes nincs, nem elhízott; $\mathrm{C}-\mathrm{O}=2$-es típusú diabetes nincs, elhízott; D-N = 2-es típusú diabetes van, nem elhízott; $\mathrm{D}-\mathrm{O}=2$-es típusú diabetes van, elhízott; $\mathrm{HbA}_{\mathrm{lc}}=$ hemoglobin- $\mathrm{A}_{\mathrm{lc}} ; \mathrm{T} 2 \mathrm{DM}=2$-es típusú cukorbetegség

p = az egy szempontos ANOVA-szignifikancia értéke

geztük lélegeztetett betegeken. A szívsebészeti anesztézia részét képező invazív és nem invazív eszközök felhelyezését követően alveolustoborzó manővert hajtottunk végre. Ezután a hemodinamikai és a változatlan légzésmechanikai paraméterek egyensúlyi állapotának beállta után artériás és centrális vénás vérgázmintákat vettünk, valamint az R-és a C-értékeket az altatógép kijelzőjéről leolvastuk. A kapnogramadatok regisztrálását követően a Zrs-regisztrátumokat is rögzítettük. Legalább három, technikailag kifogástalan kapnográfiás és Zrs-mérést végeztünk, 60 másodperces időközönként.

\section{Statisztikai analizis}

Az adatok szórását a 95\%-os konfidenciaintervallumok átlag körüli félszélességének feltüntetésével ábrázoltuk. A normális eloszlást Shapiro-Wilk-teszttel ellenőriztük. Két szempontos varianciaanalízist (ANOVA) alkalmaztunk a cukorbetegség és az elhízás hatásainak ellenőrzésére. A post-hoc elemzés Holm-Šidák többszörös összehasonlítás módszerével történt. A mintaelemszám becslését a légúti ellenállás mint elsődleges klinikai változó 25\%-os különbségének detektálására alapoztuk, mely szerint a klinikailag releváns különbségek kimutatására $10 \%$ feltételezett varibilitás, $80 \%$ erő és $5 \%$ szignifikanciaszint mellett legalább 28 beteg volt szükséges minden egyes csoportban. A statisztikai próbákat SigmaPlot szoftvercsomaggal végeztük (Verzió 13, Systat Software, Inc., Chicago, IL, USA). A p<0,05 értéket tekintettük statisztikailag szignifikánsnak.

\section{Eredmények}

Az 1. táblázat összefoglalja a négy betegcsoport demográfiai, antropometriai és főbb klinikai jellemzőit. A vizsgálati csoportok között nem volt szignifikáns különbség a magasság, az életkor, illetve az ejekciós frakció tekintetében. A várakozásoknak megfelelően a testtömeg és a
BMI szignifikánsan magasabbnak mutatkozott az elhízott betegekben $(\mathrm{p}<0,001)$. Emelkedett szérumglükózszintet $(\mathrm{p}<0,001)$ és $\mathrm{HbA}_{\mathrm{lc}}$-értéket $(\mathrm{p}<0,001)$ figyelhettünk meg a diabetesben szenvedő betegeink körében.

A protokollcsoportokban kapott légúti (Raw és $\mathrm{R}$ ), valamint légzőrendszeri szöveti mechanikai paramétereket ( $\mathrm{G}, \mathrm{H}$ és $\mathrm{C}$ ) a 2. ábra foglalja össze. A nem elhízott betegekben a T2DM szignifikánsan emelte a légúti ellenállást az Raw vonatkozásában $(\mathrm{p}<0,001)$. A légzőrendszeri szövetek disszipatív ( $\mathrm{G}$ ) és rugalmas $(\mathrm{H})$ tulajdonságaiban a T2DM szignifikáns emelkedést okozott az elhízás jelenlététől függetlenül ( $\mathrm{p}<0,001$ mindkét paraméterre). Az altatógép által kijelzett globális $\mathrm{R}$ értékeire az elhízás a cukorbetegség jelenléte nélkül is szignifikáns hatással volt $(\mathrm{p}<0,05)$, a $\mathrm{C}$ értékeit az elhízás szignifikánsan csökkentette a cukorbetegség jelenlététől függetlenül $(\mathrm{p}<0,05)$.

A kapnográfiával mért alaktényezőket és holttérparamétereket a 3. ábra szemlélteti. A nem elhízott T2DMbetegekben szignifikánsan emelkedett S3T- és S3V-értékeket találtunk ( $\mathrm{p}<0,05$ mindkét esetben). A cukorbetegségnek nem volt szignifikáns hatása a ventilációs holttér mértékére, valamint az intrapulmonalis shunt kiterjedtségére (VDE-VDB). Az időtartomány-beli és a volumetriás kapnogram 3. fázisának meredeksége szignifikánsan magasabb volt az elhízott betegekben $(p<0,001$ az S3T és az S3V esetében), míg a VDF ( $\mathrm{p}<0,001)$ és a VDB $(\mathrm{p}<0,001)$ az elhízott betegcsoportokban csökkent. Az elhízásnak nem volt hatása a VDE-re, de jelentősen megnövelte a VDE-VDB értékét $(\mathrm{p}<0,005)$ T2DM jelenléte nélkül.

A betegcsoportok gázcsere-paramétereit a 4 ábra szemlélteti. A cukorbetegség nem okozott szignifikáns eltérést a $\mathrm{PaO}_{2} / \mathrm{FiO}_{2}$, valamint a Qs/Qt értékeiben. Ezzel szemben az elhízás jelentősen csökkentette mind a $\mathrm{PaO}_{2} / \mathrm{FiO}_{2}$, mind a Qs/Qt értékeit $(\mathrm{p}<0,001$ mindkettő esetében). 


\section{Megbeszélés}

Elektív szívsebészeti beavatkozásra kerülő, invazívan lélegeztetett betegekben vizsgáltuk a cukorbetegség és az elhízás önálló és együttes hatását a légzőrendszeri mechanikára, az alveolaris ventilációra és a ventilációs-perfúziós illeszkedésre. A cukorbeteg populációban a kényszerített oszcillációs mérések emelkedett légúti ellenállást és viszkoelasztikus légzőrendszeri szöveti paramétereket, valamint megnövekedett ventilációs heterogenitást mu-
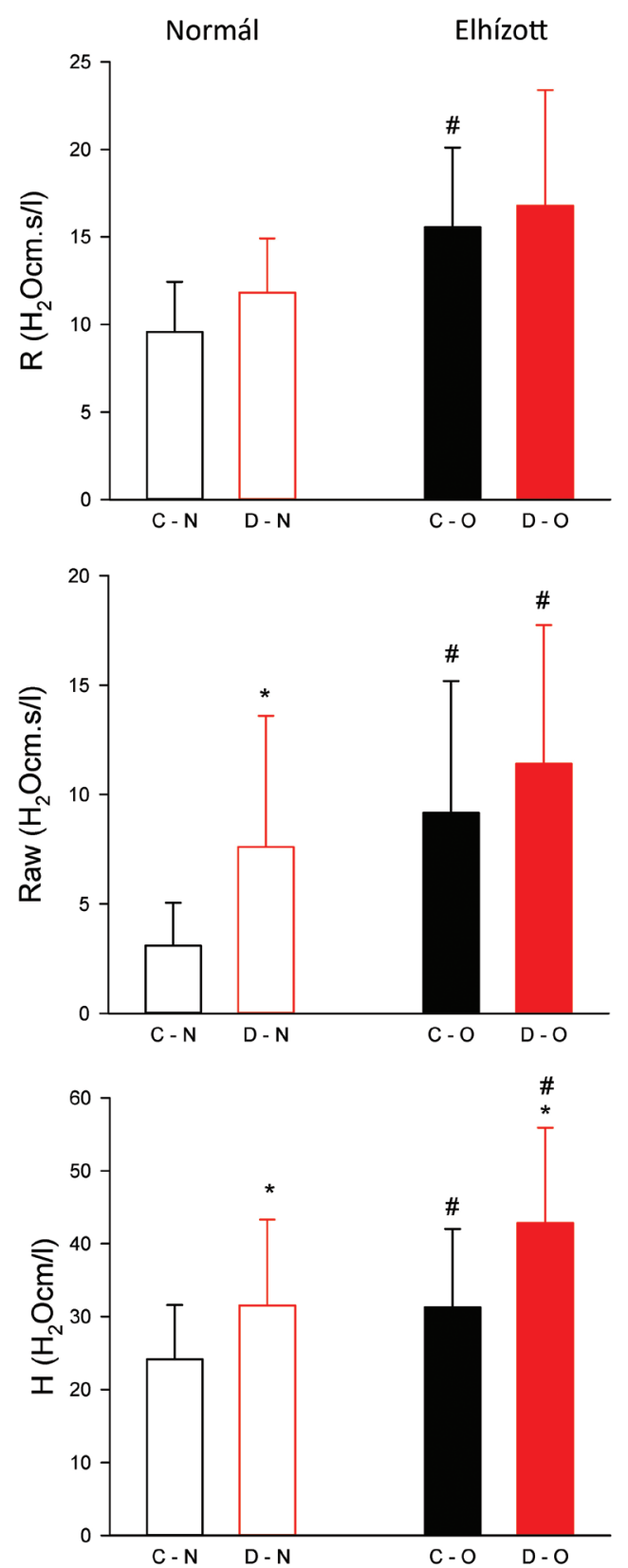

tattak. Az inhomogén alveolaris ürülést a kapnogram 3. fázisa meredekségének növekedése is alátámasztotta. Ugyanakkor cukorbetegekben a módosult légzésmechanika nem okozott kóros gázcserét, amit az egészséges, nem elhízott betegekkel egyező légzési holttér és intrapulmonalis shunt igazolt. Az elhízás a cukorbetegséghez hasonló kóros változásokat okozott a légzési mechanikában és az alveolaris heterogenitásban, ami azonban a gázcsere kóros elváltozását vonta maga után.
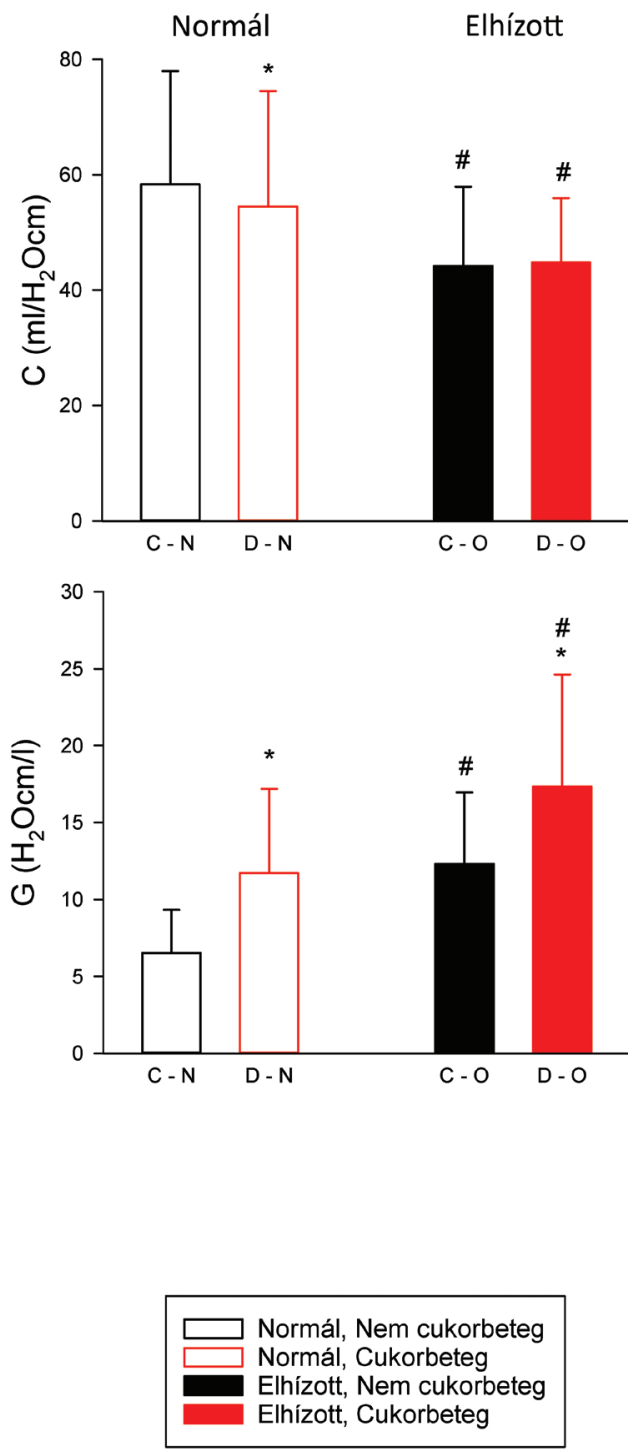

A légúti (Raw és R), valamint a légzőrendszeri szöveti $(\mathrm{G}, \mathrm{H}$, és $\mathrm{C})$ mechanikai paraméterek normáltestalkattal (N) vagy elhízással $(\mathrm{O})$ társuló kontroll- (C) és 2-es típusú diabetes mellitusban szenvedő (D) betegekben

$\mathrm{C}-\mathrm{N}$ = nincs 2 -es típusú diabetes, nem elhízott; $\mathrm{C}-\mathrm{O}=$ nincs 2 -es típusú diabetes, elhízott; $\mathrm{D}$ - $\mathrm{N}$ = 2-es típusú diabetes, nem elhízott; D-O = 2-es típusú diabetes, elhízott 

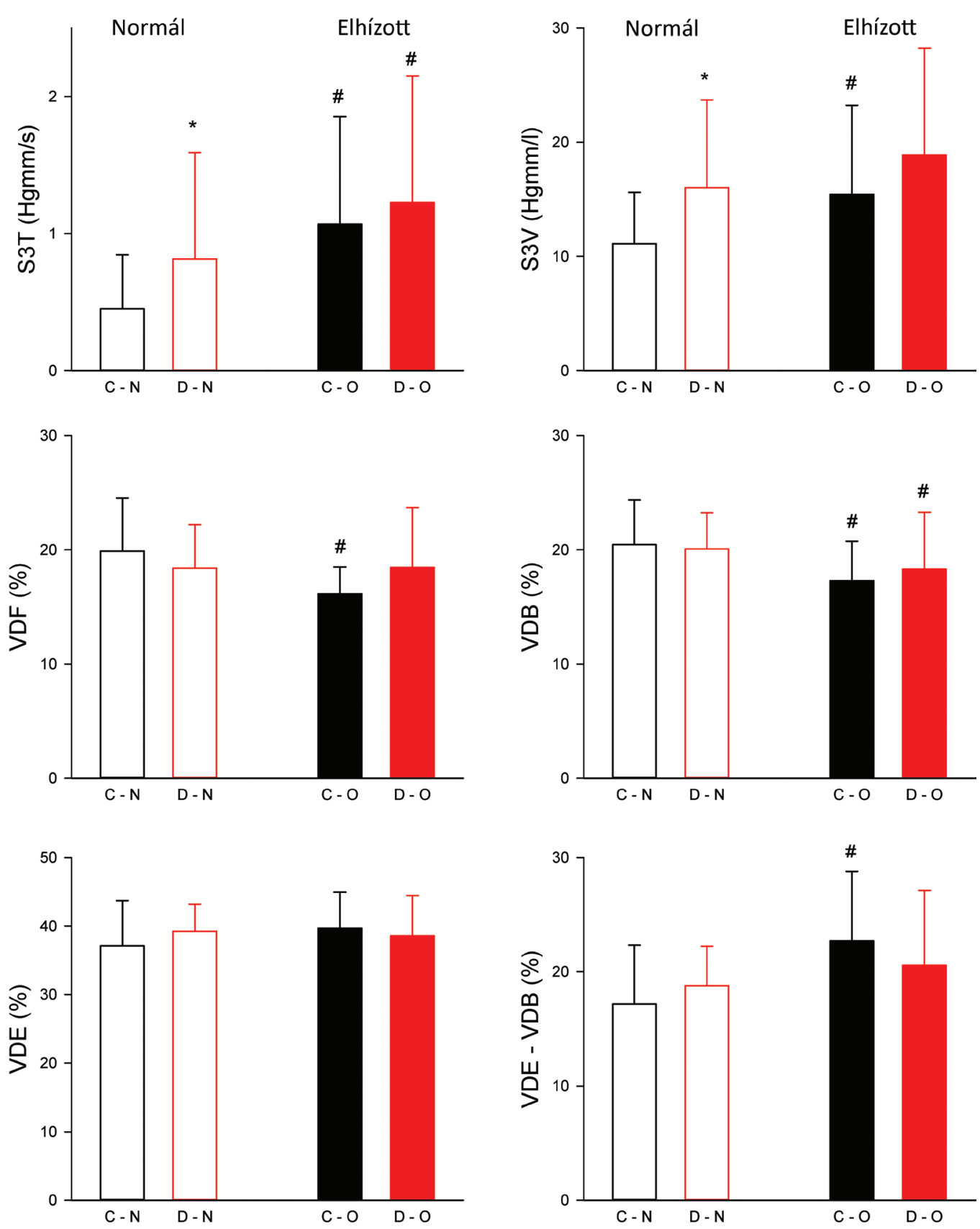

Normál, Nem cukorbeteg Normál, Cukorbeteg

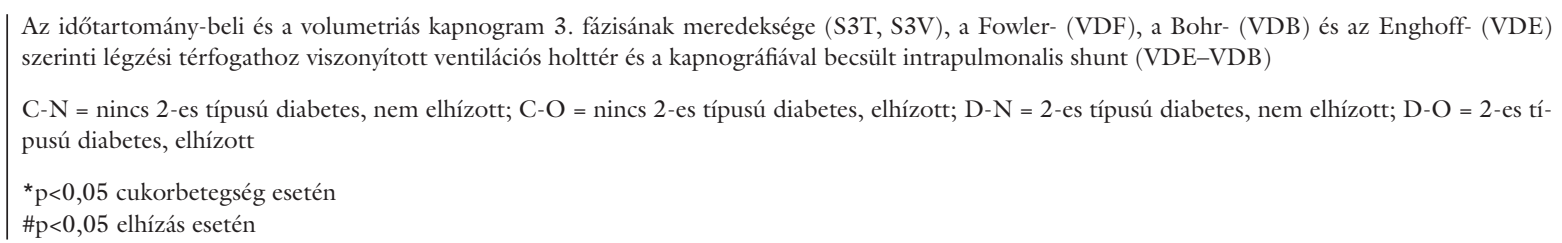

\section{A cukorbetegség hatása a légutakra}

A diabetesben szenvedő betegeknél jelentôsen megnövekedett légúti ellenállást figyeltünk meg, az elhízás esetleges meglététől függetlenül (2.ábra). Mivel a kényszerített oszcillációval meghatározott légúti ellenálláshoz
(Raw) elsősorban a nagyobb átmérőjú vezető légutak járulnak hozzá [34], ennek megfelelően ez az eredmény arra utal, hogy a cukorbetegség elsősorban a gázcserében részt nem vevő centrális légutak szúküuletét okozza. Ez az eredmény összhangban van korábbi vizsgálatokkal, melyek a spirometriás légúti csúcsáramlás (PEF) és az 
erőltetett kilégzési tüdőtérfogat $\left(\mathrm{FEV}_{1}\right)$ csökkenését mutatták [17-20], illetve a teljestest-pletizmográfiával meghatározott légúti ellenállás növekedését jelezték [24]. Számos mechanizmus járulhat hozzá a légúti elváltozásokhoz, beleértve a túlzott nyáktermelést [35], a gyulladásos jelutak aktiválódását $[36,37]$, a légúti simaizom contractilis tónusának fokozódását, a légúti simaizomsejtek proliferációját [6, 38, 39] és/vagy a csökkent vagalis tónust [40]. A cukorbetegség hatására kialakult nagyobb mértékü különbség a G értékében a H-hoz képest a perifériás légutak érintettségére utal, ami tükröződött a fokozott ventilációs heterogenitás, valamint az időtartomány-beli és a volumetriás kapnogram 3. fázisa meredekségének növekedésében. A rho-asszociált kináz fokozott aktivitása [6], valamint az $\alpha$-simaizomaktin [39], a ß-katenin [38] és/vagy a kollagén [41] túlzott expressziója lehet felelős a bronchiolaris simaizomsejtek megnövekedett contractilis tónusáért, a kóros gyulladásos jelutak lehetséges további aktiválódása mellett [36, $37,42]$.

\section{A cukorbetegség hatása a légzôrendszeri szöpetekre}

Tanulmányunk további fontos eredménye a légzőrendszeri szövetek mechanikai paramétereinek kényszerített oszcillációs módszerrel mért növekedése cukorbetegekben. Ez nagyobb belső súrlódással rendelkező (viszkózusabb, azaz növekedett disszipáció vagy energiaveszteség) és merevebb (növekedett elasztancia és csökkent compliance) légzőrendszeri szövetek képében nyilvánult meg (2. ábra). Mivel a cukorbetegség állatkísérletes mo- delljében a tüdőszövetekben lévő kollagénrostok menynyisége pozitív korrelációt mutatott a G- és a H-értékekkel [41], a felhalmozódott AGE-k az extracelluláris tüdőszöveti mátrix kóros elváltozását okozzák, ezzel módosítva a szövetek szerkezetét. Ennek megfelelően a szövetekre jellemző megnövekedett energiadisszipáció és rugalmatlanság a strukturális elváltozásokra vezethető vissza cukorbetegekben [12, 15, 42-45].

A szöveti rugalmasság kétféle meghatározása rávilágított, hogy a $\mathrm{H}$ markáns emelkedését a $\mathrm{C}$ enyhébb csökkenése kísérte (2.ábra). Ez a látszólagos ellentmondás a paraméterek mérési körülményeiben meglévő különbségekkel magyarázható. A kényszerített oszcillációs $\mathrm{H}$ értékét kilégzésvégi szünetben rögzítettük, míg a $\mathrm{C}$ a légzôrendszer tágulékonyságát belégzésvégi állapotban jellemzi. Ennek megfelelően a $\mathrm{H}$ értékeiben jelentkező kifejezettebb különbség a kilégzésvégi fokozott tüdőtérfogat-csökkenéssel magyarázható, ami cukorbetegekben az alveolusok fokozottabb záródási hajlamát mutatja. Ez a légzésmechanikai eredmény a II. típusú pneumocyták károsodására vezethető vissza, amely a felületaktív anyagok bioszintézisének és szekréciójának csökkenését idézi elő $[46,47]$.

\section{A cukorbetegség hatása a gázcserére}

Vizsgálatunk egyik leginkább figyelemreméltó eredménye, hogy a cukorbetegek romló légzésmechanikai statusát nem követi a gázcsere-paraméterek kóros elváltozása, sem a légzési holtterek (3. ábra), sem az tüdőoxigenizációs index vagy az intrapulmonalis shunt vonatkozásában (4. ábra). A fenntartott, fiziológiásnak megfelelő gáz-
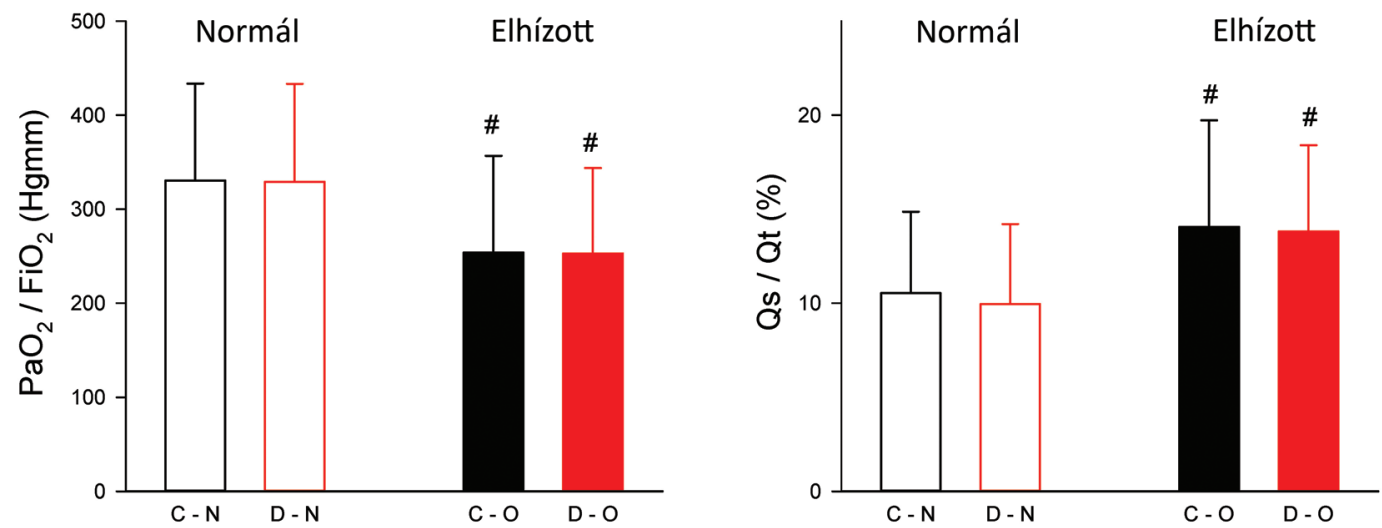
cseréért felelős mechanizmusok nem teljesen tisztázottak. A cukorbetegek az endothel diszfunkciója miatt hajlamosak a fokozottabb generalizált vasoconstrictiv válaszra $[8,9,11,12,15,42]$. Ez fokozza a pulmonalis érrendszeri contractilitast hypoxiás környezetben, azaz a hypoxiás pulmonalis vasoconstrictiót. Az intrapulmonalis vér redisztribúciója a jól ventilált [12] tüdőrégiókba ezáltal feltételezhetően hatékonyabb, ami csökkentheti a ventilációs/perfúziós illeszkedési zavarokat. Ennek a hatékony kompenzációs mechanizmusnak a meglétét támasztja alá mind a kapnográfiás úton (VDE-VDB, 3. ábra), mind a vérgázparaméterekból (Qs/Qt, 4. ábra) számított intrapulmonalis shuntfrakció változatlansága cukorbetegekben.

\section{Az elhizás hatása a légzésfunkcióra}

A jelen tanulmányban az elhízást mint potenciális rizikófaktort a cukorbetegségtől függetlenül is vizsgáltuk annak érdekében, hogy egyértelmú képet kaphassunk e gyakori kórkép légzőszervi következményeiről. A légzőrendszeri mechanikai paraméterekben az elhízás és a cukorbetegség hasonló irányú és mértékü elváltozásokat okozott. Az elhízás légzésmechanikai hatása összhangban van korábbi eredményekkel, melyek a légutak és a szövetek mechanikai károsodását [48, 49] és az inhomogén tüdőventilációt $[50,51]$ emelték ki. Ugyanakkor a mechanikai változásokért felelős mechanizmusok az elhízott betegekben alapvetően különböznek a cukorbetegségben szenvedő személyekéitől. Obesitasban elsődlegesen regionális atelectasia és következményes légzésitérfogat-csökkenés jelentkezik, melyet a rekeszizom cranialis irányú elmozdulása okoz a hasi oldalról fellépő mechanikai terhelés következtében. Ezenkívül az elhízás és a cukorbetegség együttes megléte a légutak és a szöveti mechanikai paraméterek kumulatív romlását okozta. Ez az additív hatás összefüggésbe hozható a külső mechanikai terhelés [52] és az alveolusok fokozott kollapszushajlamának együttes jelenlétével [46, 47].

A cukorbetegséggel ellentétben az elhízott betegekben a légzésmechanika romlása a kóros gázcsere-paraméterekben is tükröződött. A csökkent anatómiai holttér (VDF) a tüdőszövet összenyomódásának tulajdonítható, mely a vezető légutak gáztartalmának csökkenéséhez is vezet. Az elhízott betegek kisebb élettani holttere (VDB) a tüdó és a szív cranialis eltolódásával magyarázható, amely a tüdőparenchyma West I. zónájának csökkenését idézi elö. Ezenkívül az elhízott betegeknél a csökkent $\mathrm{PaO}_{2} / \mathrm{FiO}_{2}$ bizonyítja a tüdő károsodott oxigénellátó képességét (4. ábra), amely csak részben kompenzálódik a pulmonalis vascularis contractilitassal [53].

Tanulmányunk limitációja, hogy a vizsgálatban részt vevő betegek elektív szívmütétre kerültek, amely befolyásolhatta a légzésfunkció-változás mértékét és jellegét. A szívbetegségek megoszlása azonban homogén volt a betegcsoportok között, így a cardiopulmonalis interakció valószínúleg nem torzította lényegesen a vizsgálati csoportok közötti különbségeket. Ezenkívül figyelmet fordítottunk az egyes csoportok populációjának homogenizálására olyan tényezők kizárásával, mint a dohányzás és a COPD, amelyek módosíthatták volna a tüdő kiinduló légzésmechanikai és funkcionális statusát. További módszertani tényezőként az intakt mellkasfal befolyásolhatta a $\mathrm{G}$ és $\mathrm{H}$ paraméterek állapotfüggő különbségeinek mértékét.

\section{Következtetés}

Összefoglalva, a cukorbetegség növelte a centrális és a perifériás légutak ellenállását, valamint rontotta a légzőrendszeri szövetek disszipatív és elasztikus tulajdonságait. Ezen mechanikai változások a ventiláció heterogenitásának és a tüdő kollapszushajlamának növekedéséhez vezettek. Ezeket a mechanikai rendellenességeket ellensúlyozta a pulmonalis érrendszer hypoxiás ingerekre adott fokozott contractilis válasza, amely képes volt fenntartani a tüdő normális intrapulmonalis shuntfrakcióját és oxigenizációs képességét. Bár az elhízás a cukorbetegséghez hasonló módon rontotta a globális légzésmechanikát, a tüdőt ért külső kompresszió atelectasiához vezetett, mely a gázcsere romlásában és az intrapulmonalis shuntfrakció emelkedésében is megnyilvánult. A cukorbetegség és az elhízás egyidejű jelenléte fokozottan károsította a légutak és a légzőrendszeri szövetek mechanikai tulajdonságait. Ezen kóros elváltozások rávilágítanak a magas PEEP és alacsony VT melletti, tüdőprotektív ventiláció fontosságára, cukorbetegségben a tüdő intrinsic kollapszushajlama miatt, kóros elhízásban pedig az extrinsic kompressziós terhelés következtében. Ezek additív jelenléte elhízott cukorbetegekben különös jelentóséget nyerhet.

Anyagi támogatás: Ezt a munkát az Országos Tudományos Kutatási Alap (OTKA K115253) és a magyarországi Gazdaságfejlesztési és Innovációs Operatív Program támogatta az Európai Unió és az Európai Regionális Fejlesztési Alap társfinanszírozásával (GINOP-2.3.2-152016-00006).

Szerzôi munkamegosztás: K. B. N., S. R. és B. B. az adatgyưjtésben, B. Á. L., F. H. G., T. J., K. A. és S. Á. az adatelemzésben és a statisztikai értékelésben, P. F. az ábrák szerkesztésében, P. F., B. B. és L. Cs. a kézirat elkészítésében vett részt. A cikk végleges változatát valamennyi szerző elolvasta és jóváhagyta.

Érdekeltségek: A szerzők a kézirat elkészítésével kapcsolatban pénzügyi vagy egyéb személyes érdekeltséggel nem rendelkeztek. 


\section{Köszönetnyilvánítás}

A szerzők köszönetet mondanak a Szegedi Tudományegyetem Belgyógyászati Klinika Szívsebészeti Osztálya munkatársainak az együttmúködésükért.

\section{Irodalom}

[1] NCD Risk Factor Collaboration (NCD-RisC). Worldwide trends in diabetes since 1980: a pooled analysis of 751 populationbased studies with 4.4 million participants. Lancet 2016; 387(10027): 1513-1530. [Erratum: Lancet 2017; 389(10068): e2.]

[2] Ogurtsova K, da Rocha Fernandes JD, Huang Y, et al. IDF Diabetes Atlas: Global estimates for the prevalence of diabetes for 2015 and 2040. Diabetes Res Clin Pract. 2017; 128: 40-50.

[3] Sjoding MW, Prescott HC, Wunsch H, et al. Longitudinal changes in ICU admissions among elderly patients in the United States. Crit Care Med. 2016; 44: 1353-1360.

[4] Jermendy Gy, Kiss Z, Rokszin Gy, et al. Changes in mortality rates and ratios in people with pharmacologically treated type 2 diabetes mellitus between 2001 and 2016 in Hungary. Diabetes Res Clin Pract. 2020; 163: 108134.

[5] Jermendy Gy. De-escalation of antihyperglycemic treatment in patients with type 2 diabetes - when less is more. [Az antihyperglykaemiás terápia deeszkalációja 2 -es típusú diabetesben amikor a kevesebb több.] Orv Hetil. 2019; 160: 1207-1215. [Hungarian]

[6] Abd-Elrahman KS, Walsh MP, Cole WC. Abnormal Rho-associated kinase activity contributes to the dysfunctional myogenic response of cerebral arteries in type 2 diabetes. Can J Physiol Pharmacol. 2015; 93: 177-184.

[7] Gregg EW, Williams DE, Geiss L. Changes in diabetes-related complications in the United States. N Engl J Med. 2014; 371: 286-287

[8] Rask-Madsen C, King GL. Vascular complications of diabetes: mechanisms of injury and protective factors. Cell Metab. 2013 17: 20-33.

[9] Xu RS. Pathogenesis of diabetic cerebral vascular disease complication. World J Diabetes 2015; 6: 54--66.

[10] Giacco F, Brownlee M. Oxidative stress and diabetic complications. Circ Res. 2010; 107: 1058-1070.

[11] Paneni F, Beckman JA, Creager MA, et al. Diabetes and vascular disease: pathophysiology, clinical consequences, and medical therapy: part I. Eur Heart J. 2013; 34: 2436-2443.

[12] Brownlee M. Biochemistry and molecular cell biology of diabetic complications. Nature 2001; 414: 813-820.

[13] Stirban A, Gawlowski T, Roden M. Vascular effects of advanced glycation endproducts: clinical effects and molecular mechanisms. Mol Metab. 2014; 3: 94-108.

[14] El-Yazbi AF, Abd-Elrahman KS. ROK and arteriolar myogenic tone generation: molecular evidence in health and disease. Front Pharmacol. 2017; 8: 87.

[15] Brownlee M. The pathobiology of diabetic complications: a unifying mechanism. Diabetes 2005; 54: 1615-1625.

[16] Lecube A, Simó R, Pallayova M, et al. Pulmonary function and sleep breathing: two new targets for type 2 diabetes care. Endocr Rev. 2017; 38: 550-573

[17] Kuziemski K, Słomiński W, Jassem E. Impact of diabetes mellitus on functional exercise capacity and pulmonary functions in patients with diabetes and healthy persons. BMC Endocr Disord. 2019; 19:2

[18] Martín-Frías M, Lamas A, Lara E, et al. Pulmonary function in children with type 1 diabetes mellitus. J Pediatr Endocrinol Metab. 2015 ; 28 : 163-169.
[19] Schnapf BM, Banks RA, Silverstein JH, et al. Pulmonary func tion in insulin-dependent diabetes mellitus with limited joint mobility. Am Rev Respir Dis. 1984; 130: 930-932.

[20] Wanke T, Formanek D, Auinger M, et al. Inspiratory muscle performance and pulmonary function changes in insulin-dependent diabetes mellitus. Am Rev Respir Dis. 1991; 143: 97-100.

[21] Antonelli Incalzi R, Fuso L, Giordano A, et al. Neuroadrenergic denervation of the lung in type I diabetes mellitus complicated by autonomic neuropathy. Chest 2002; 121: 443-451.

[22] Bertherat J, Lubetzki J, Lockhart A, et al. Decreased bronchial response to methacholine in IDDM patients with autonomic neuropathy. Diabetes 1991; 40: 1100-1106.

[23] Mancini M, Filippelli M, Seghieri G, et al. Respiratory muscle function and hypoxic ventilatory control in patients with type I diabetes. Chest 1999; 115: 1553-1562.

[24] van Gent R, Brackel HJ, de Vroede M, et al. Lung function abnormalities in children with type I diabetes. Respir Med. 2002; 96: 976-978.

[25] Eaton T, Withy S, Garrett JE, et al. Spirometry in primary care practice: the importance of quality assurance and the impact of spirometry workshops. Chest 1999; 116: 416-423.

[26] Giner J, Plaza V, Rigau J, et al. Spirometric standards and patient characteristics: an exploratory study of factors affecting fulfillment in routine clinical practice. Respir Care 2014; 59: 18321837 .

[27] Babik B, Asztalos T, Peták F, et al. Changes in respiratory mechanics during cardiac surgery. Anesth Analg. 2003; 96: 12801287.

[28] Hantos Z, Daróczy B, Suki B, et al. Input impedance and peripheral inhomogeneity of dog lungs. J Appl Physiol. 1992; 72: 168178.

[29] Babik B, Csorba Z, Czövek D, et al. Effects of respiratory mechanics on the capnogram phases: importance of dynamic compliance of the respiratory system. Crit Care 2012; 16: Rl77.

[30] Fowler WS. Lung function studies; the respiratory dead space. Am J Physiol. 1948; 154: 405-416.

[31] Balogh AL, Peták F, Fodor GH, et al. Capnogram slope and ventilation dead space parameters: comparison of mainstream and sidestream techniques. Br J Anaesth. 2016; 117: 109-117.

[32] Tusman G, Sipmann FS, Bohm SH. Rationale of dead space measurement by volumetric capnography. Anesth Analg. 2012; 114: 866-874.

[33] Csorba Z, Petak F, Nevery K, et al. Capnographic parameters in ventilated patients: correspondence with airway and lung tissue mechanics. Anesth Analg. 2016; 122: 1412-1420.

[34] Bayat S, Strengell S, Porra L, et al. Methacholine and ovalbumin challenges assessed by forced oscillations and synchrotron lung imaging. Am J Respir Crit Care Med. 2009; 180: 296-303.

[35] Oliveira TL, Candeia-Medeiros N, Cavalcante-Araújo PM, et al. SGLTl activity in lung alveolar cells of diabetic rats modulates airway surface liquid glucose concentration and bacterial proliferation. Sci Rep. 2016; 6: 21752.

[36] Duncan BB, Schmidt MI, Pankow JS, et al. Low-grade systemic inflammation and the development of type 2 diabetes: the atherosclerosis risk in communities study. Diabetes 2003; 52: 17991805.

[37] Schmidt MI, Duncan BB, Sharrett AR, et al. Markers of inflammation and prediction of diabetes mellitus in adults (Atherosclerosis Risk in Communities study): a cohort study. Lancet 1999; 353: 1649-1652

[38] Singh S, Bodas M, Bhatraju NK, et al. Hyperinsulinemia adversely affects lung structure and function. Am J Physiol Lung Cell Mol Physiol. 2016; 310: L837-L845.

[39] Wang CC, Gurevich I, Draznin B. Insulin affects vascular smooth muscle cell phenotype and migration via distinct signaling pathways. Diabetes 2003; 52: 2562-2569. 
[40] Douglas NJ, Campbell IW, Ewing DJ, et al. Reduced airway vagal tone in diabetic patients with autonomic neuropathy. Clin Sci (Lond) 1981; 61: 581-584.

[41] Südy R, Schranc Á, Fodor GH, et al. Lung volume dependence of respiratory function in rodent models of diabetes mellitus. Respir Res. 2020; 21: 82.

[42] Babik B, Peták F, Agócs S, et al. Diabetes mellitus: endothelial dysfunction and changes in hemostasis. [Diabetes mellitus: endotheldiszfunkció és haemostasiselváltozások.] Orv Hetil. 2018; 159: 1335-1345. [Hungarian]

[43] Hollenbach J, Lopez-Rodriguez E, Mühlfeld C, et al. Voluntary activity modulates sugar-induced elastic fiber remodeling in the alveolar region of the mouse lung. Int J Mol Sci. 2019; 20: 2438.

[44] Ofulue AF, Thurlbeck WM. Experimental diabetes and the lung. II. In vivo connective tissue metabolism. Am Rev Respir Dis. 1988; 138: 284-289.

[45] Sandler M. Is the lung a 'target organ' in diabetes mellitus? Arch Intern Med. 1990; 150: 1385-1388.

[46] Foster DJ, Ravikumar P, Bellotto DJ, et al. Fatty diabetic lung: altered alveolar structure and surfactant protein expression. Am J Physiol Lung Cell Mol Physiol. 2010; 298: L392-L403.

[47] Sugahara K, Ezaki K, Kaneko T, et al. Studies of the lungs in diabetes mellitus. II. Phospholipid analyses on the surfactant from broncho-alveolar lavage fluid of alloxan-induced diabetic rats. Biochem Biophys Res Commun. 1981; 98: 163-168.
[48] Kalchiem-Dekel O, Hines SE. Forty years of reference values for respiratory system impedance in adults: 1977-2017. Respir Med. 2018; 136: 37-47.

[49] Peters U, Dechman G, Hernandez P, et al. Improvement in upright and supine lung mechanics with bariatric surgery affects bronchodilator responsiveness and sleep quality. J Appl Physiol. 2018; 125: 1305-1314.

[50] Böhm SH, Maisch S, von Sandersleben A, et al. The effects of lung recruitment on the phase III slope of volumetric capnography in morbidly obese patients. Anesth Analg. 2009; 109: 151159.

[51] Tusman G, Groisman I, Fiolo FE, et al. Noninvasive monitoring of lung recruitment maneuvers in morbidly obese patients: the role of pulse oximetry and volumetric capnography. Anesth Analg. 2014; 118: 137-144.

[52] Boriek AM, Lopez MA, Velasco C, et al. Obesity modulates diaphragm curvature in subjects with and without COPD. Am J Physiol Regul Integr Comp Physiol. 2017; 313: R620-R629.

[53] Rivas E, Arismendi E, Agustí A, et al. Ventilation/perfusion distribution abnormalities in morbidly obese subjects before and after bariatric surgery. Chest 2015; 147: 1127-1134.

(Babik Barna dr., Szeged, Semmelweis u. 6., 6720 e-mail: babikbarna@gmail.com)

\section{"Iter est quacumque dat prior vestigium." (Mindenütt út van, ahol egy előtted járó nyomot hagy.)}

A cikk a Creative Commons Attribution 4.0 International License (https://creativecommons.org/licenses/by/4.0/) feltételei szerint publikált Open Access közlemény, melynek szellemében a cikk bármilyen médiumban szabadon felhasználható, megosztható és újraközölhető, feltéve, hogy az eredeti szerző és a közlés helye, illetve a CC License linkje és az esetlegesen végrehajtott módositások feltüntetésre kerülnek. (SID_1) 